\title{
An Analysis of ZnS:Cu Phosphor Layer Thickness Influence on Electroluminescence Device Performances
}

\author{
Pakpoom Chansri, ${ }^{1}$ Somchai Arunrungrusmi, ${ }^{1}$ Toshifumi Yuji, ${ }^{2}$ and Narong Mungkung ${ }^{1}$ \\ ${ }^{1}$ Plasma and Electrical Discharge Laboratory, King Mongkut's University of Technology Thonburi, Bangkok 10140, Thailand \\ ${ }^{2}$ Faculty of Education, University of Miyazaki, Miyazaki 889-2192, Japan \\ Correspondence should be addressed to Narong Mungkung; narong_kmutt@hotmail.com
}

Received 7 February 2017; Revised 30 March 2017; Accepted 29 May 2017; Published 24 July 2017

Academic Editor: Yong Li

Copyright (c) 2017 Pakpoom Chansri et al. This is an open access article distributed under the Creative Commons Attribution License, which permits unrestricted use, distribution, and reproduction in any medium, provided the original work is properly cited.

\begin{abstract}
Electroluminescence (EL) device is a new technology; its thickness is within micrometer range which can bend more easily and emit light. However, the thickness of $\mathrm{ZnS}: \mathrm{Cu}$ phosphor layer may affect the light intensity, so we have analyzed the thickness of $\mathrm{ZnS}: \mathrm{Cu}$ phosphor layer on EL device. The EL devices consist of ITO:PET/ZnS:Cu phosphor/insulator $\left(\mathrm{BaTiO}_{3}\right) / \mathrm{Ag}$ electrode. The EL devices were fabricated in changing thickness $10 \mu \mathrm{m}, 30 \mu \mathrm{m}$, and $50 \mu \mathrm{m}$. At $100 \mathrm{~V} 400 \mathrm{~Hz}$, the luminance of EL devices was $51.22 \mathrm{~cd} / \mathrm{m}^{2} \mathrm{for}$ thickness $30 \mu \mathrm{m}$ more than that of $45.78 \mathrm{~cd} / \mathrm{m}^{2}$ (thickness: $10 \mu \mathrm{m}$ ) and $42.58 \mathrm{~cd} / \mathrm{m}^{2}$ (thickness: $50 \mu \mathrm{m}$ ). However, the peak light intensity was achieved at wavelength of $507 \mathrm{~nm}$ which was not influenced by the thickness of the $\mathrm{ZnS}$ :Cu phosphor. The use of the $\mathrm{ZnS}: \mathrm{Cu}$ phosphor layer at thickness $30 \mu \mathrm{m}$ in the EL device significantly improves the luminescence performance.
\end{abstract}

\section{Introduction}

The light-emitting devices such as LCD (liquid crystal display), LED (light-emitting diode) and OLED (organic light-emitting diode), ECL (electrochemical luminescence), and EL (electroluminescence) [1-6] are very popular and widely used in commercial. The fabrication of these devices is difficult for large-area light-emitting devices, in which the vacuum evaporation processes are vacuum-evaporated by drying at high temperature. The organic materials were heated by vacuum evaporation causing the deformation of the molecular structure and a reaction between molecules [5]. Electroluminescence (EL) devices are one choice for the display application. It is a new technology and is the emission of light from a phosphor material layer when an electric current is passed through it [7-11]. EL devices are thin and can bend on the device. It was widely used in display advertise, brightness, and low current. The EL device consists of the dielectric (light-emitting phosphor) layer and two electrode overlapping layers. The structure of the EL devices is the same as a capacitor [12].

For EL devices, the voltage applied is about $100-500 \mathrm{~V}$ and frequency is about $400-800 \mathrm{~Hz}$. The electric field flows through the phosphor layer causing the distribution of phosphor material [13] and collision electron fast transfer between the electrode which is based on frequency [14-18].

The light-emitting phosphor material had been developed by researchers such as $\mathrm{ZnS}: \mathrm{Cu}, \mathrm{ZnS}: \mathrm{Cu}, \mathrm{Cl}, \mathrm{ZnS}: \mathrm{Mn}$, and another phosphor material [17-23]. The researchers had researched on EL devices which can explain the following literatures. Han et al. [24] synthesized $\mathrm{ZnS}: \mathrm{Cu}, \mathrm{Cl}$ phosphors with the coating $\mathrm{TiO}_{2}$ for EL panel that was showing yellow-green color emission. Kim [25] investigates the effect of EL performance by using $\mathrm{ZnS}: \mathrm{Cu}, \mathrm{Cl}$ phosphor powder that was used as emitting organic dye [(phosphor + coumarin 6 (C6)]. High EL intensity performance and response of bluish-green color was found. These researches investigate not the thickness of phosphor layer causing short-time stable. The thick film of lightemitting phosphor layer has importance to luminance performance which may affect to the thickness of lightemitting phosphor layer.

In this paper, we present the optimized thickness of phosphor layer for EL device by screen printing coated on 


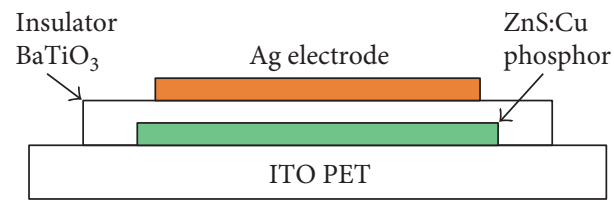

FIgURE 1: The structure of EL device using $\mathrm{ZnS}$ :Cu phosphor.

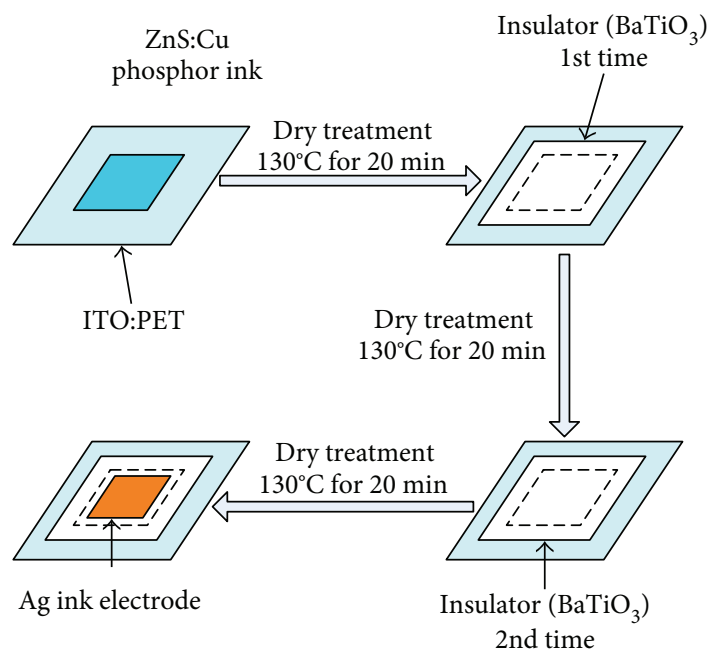

FIgURE 2: The process of EL device using $\mathrm{ZnS}: \mathrm{Cu}$ phosphor.

plastic electrode transparent (PET). The phosphor uses $\mathrm{ZnS}: \mathrm{Cu}$ powder which responded to green color emission. The result of electrical and luminance properties is confirmed to a performance of the EL device. The condition thickness of phosphor layer for EL device is significant to light intensity efficiency.

\section{Experimental Setup}

Figure 1 shows schematic diagram of EL device which consists of ITO:PET/ZnS:Cu phosphor/insulator $\left(\mathrm{BaTiO}_{3}\right) / \mathrm{Ag}$ electrode. The thickness of $\mathrm{ZnS}: \mathrm{Cu}$ phosphor was prepared $10 \mu \mathrm{m}$ to $50 \mu \mathrm{m}$. The $\mathrm{ZnS}: \mathrm{Cu}$ phosphor ink was fabricated by $\mathrm{ZnS}: \mathrm{Cu}$ phosphor powder at $20-32 \mu \mathrm{m}$ of resolution (ZnS:Cu phosphor; Osram Sivanier) and binder ink (X-100, Triton). Both materials were mixed by 1 gram of $\mathrm{ZnS}: \mathrm{Cu}$ phosphor powder and 1.5 of X-100, stirring for $10 \mathrm{~min}$ at $800 \mathrm{rpm}$ or $15 \mathrm{~min}$ or until homogeneous.

The EL device with $\mathrm{ZnS}: \mathrm{Cu}$ phosphor was fabricated as mixed $\mathrm{ZnS}: \mathrm{Cu}$ phosphor ink coated on ITO:PET in the area $3 \times 3 \mathrm{~cm}^{2}$ and dryer treatment $130^{\circ} \mathrm{C}$ for $20 \mathrm{~min}$. After that, the insulator $\left(\mathrm{BaTiO}_{3}\right)$ was coated on phosphor ink in the area $4 \times 4 \mathrm{~cm}^{2}$ and dryer treatment $130^{\circ} \mathrm{C}$ for $20 \mathrm{~min}$ (insulator coated on phosphor 2 times) and the Ag electrode was coated on insulator paste in the area $2 \times 2 \mathrm{~cm}^{2}$ and dryer treatment $130^{\circ} \mathrm{C}$ for $20 \mathrm{~min}$ [26]. These were shown in Figure 2. For the luminance and electrical properties, the spectral brightness analyzer (Konica Minolta, CS-2000), AC power supply (Acsoon $\left.{ }^{\circledR} \mathrm{AF} 400 \mathrm{M}\right)$, and digital storage oscilloscope (Tektronix TDS 3014B) were used.

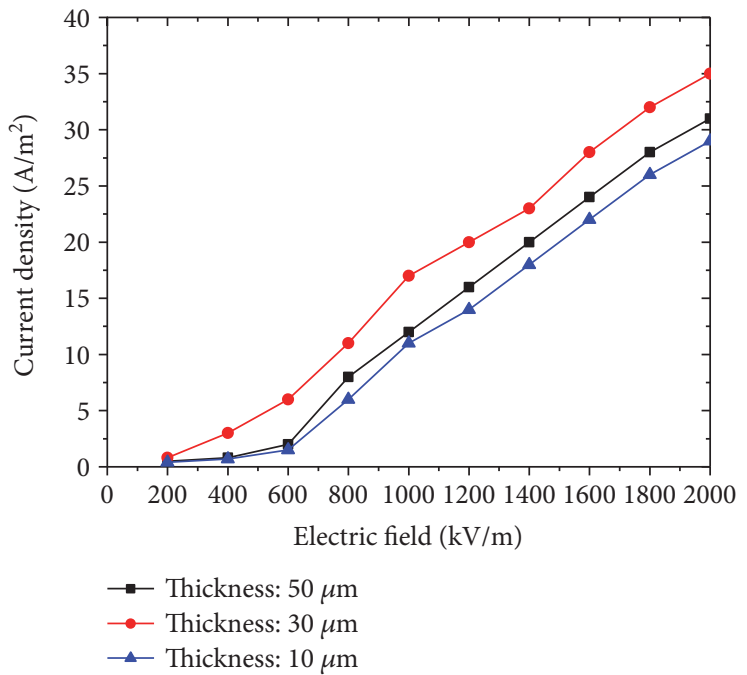

Figure 3: I-V curve of EL device with $\mathrm{ZnS}: \mathrm{Cu}$ phosphor change in thickness $10 \mu \mathrm{m}, 30 \mu \mathrm{m}$, and $50 \mu \mathrm{m}$.

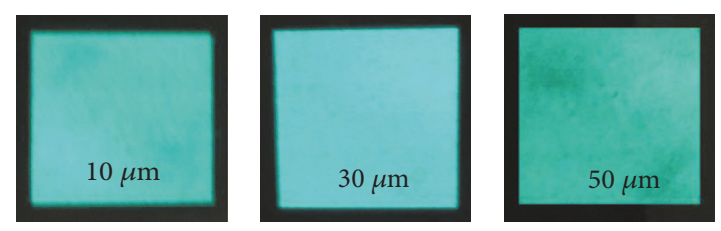

FIgURE 4: Lighting emission of EL device with $\mathrm{ZnS}: \mathrm{Cu}$ phosphor change in thickness $10 \mu \mathrm{m}, 30 \mu \mathrm{m}$, and $50 \mu \mathrm{m}$.

\section{Results}

3.1. Electrical Properties. Figure 3 shows the relationship between current and voltage ( $I$ - $V$ curve) of the EL device with $\mathrm{ZnS}: \mathrm{Cu}$ phosphor change in thickness $10 \mu \mathrm{m}, 30 \mu \mathrm{m}$, and $50 \mu \mathrm{m}$. The applied input voltage and frequency of the cell were $0-200 \mathrm{~V}$ and $400 \mathrm{~Hz}$ when it was tested. The maximum current density was $39.2 \mathrm{~A} / \mathrm{m}^{2}$ for thickness $30 \mu \mathrm{m}$ (thickness: $30 \mu \mathrm{m}$ ) which is more than the maximum current density $27.1 \mathrm{~A} / \mathrm{m}^{2}$ for thickness $10 \mu \mathrm{m}$ (thickness: $10 \mu \mathrm{m}$ ) and $30.2 \mathrm{~A} / \mathrm{m}^{2}$ for thickness $50 \mu \mathrm{m}$ (thickness: $50 \mu \mathrm{m}$ ) electrodes, at $1000 \mathrm{kV} / \mathrm{m}$ (about input voltage at $100 \mathrm{~V}$ ). The current of thickness at $10 \mu \mathrm{m}$ was less than that of thickness at $30 \mu \mathrm{m}$ due to the electric charge flow through decreases in the area of $\mathrm{ZnS}: \mathrm{Cu}$ phosphor layer [22]. The current of thickness at $50 \mu \mathrm{m}$ was more than that of thickness at $30 \mu \mathrm{m}$ because of the large area of $\mathrm{ZnS}: \mathrm{Cu}$ phosphor causing distance-free electric field and the electric charge cannot flow from ITO:PET to Ag electrode [27].

3.2. Luminance Properties. Figure 4 shows lighting emission of EL device with $\mathrm{ZnS}: \mathrm{Cu}$ phosphor change in thickness at $10 \mu \mathrm{m}, 30 \mu \mathrm{m}$, and $50 \mu \mathrm{m}$. At applied voltage $100 \mathrm{~V}$, the thickness of $\mathrm{ZnS}: \mathrm{Cu}$ phosphor $30 \mu \mathrm{m}$ showed brightness more than that of the thickness at $10 \mu \mathrm{m}$ and $50 \mu \mathrm{m}$.

The peak intensity spectra show wavelength and response color. The EL device with $\mathrm{ZnS}: \mathrm{Cu}$ phosphor layer 


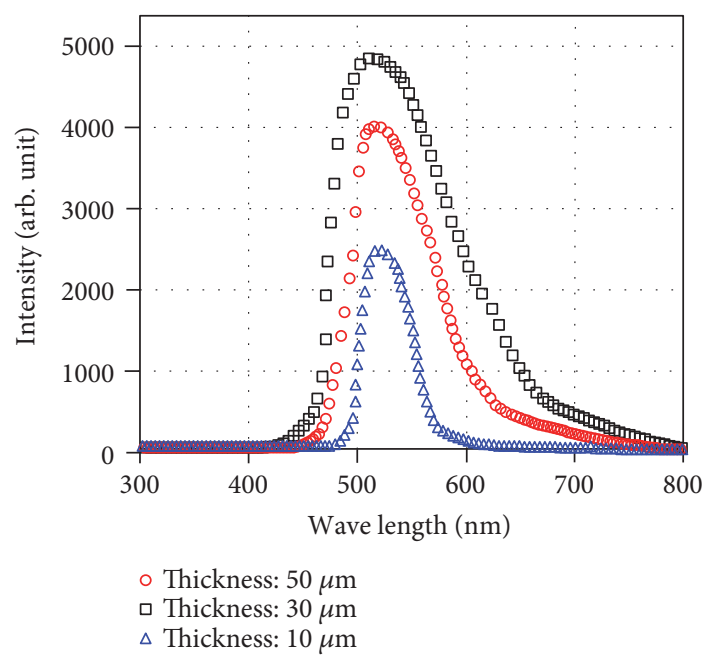

FIGURE 5: The intensity spectral of EL device with $\mathrm{ZnS}$ :Cu phosphor change in all thickness.

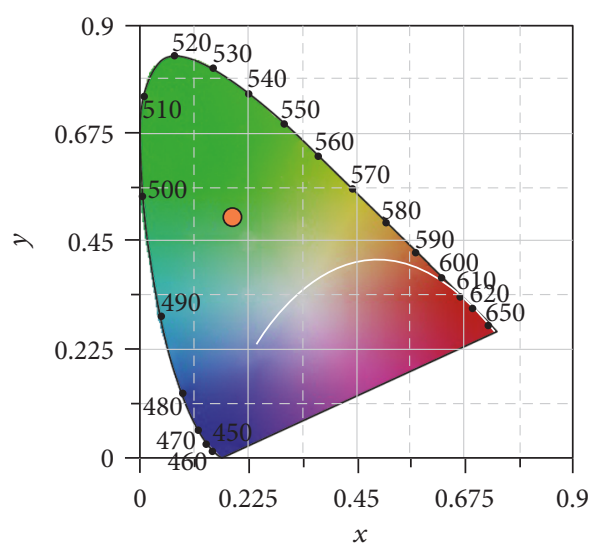

FIGURE 6: CIE $x, y$ chromaticity diagram of EL device with $\mathrm{ZnS}: \mathrm{Cu}$ phosphor change in all thickness.

is represented at all thickness for test and build. The light emission spectra of the EL device with $\mathrm{ZnS}: \mathrm{Cu}$ phosphor change in thickness $10 \mu \mathrm{m}, 30 \mu \mathrm{m}$, and $50 \mu \mathrm{m}$ are shown in Figure 5 . The peak intensity at a wavelength of $507 \mathrm{~nm}$ was not influenced by the operation condition thickness of EL devices at $100 \mathrm{~V}$ AC and $400 \mathrm{~Hz}$. The EL devices showed green-blue emission in all thickness, and thus it was confirmed that the thickness does not influence the EL device's luminous color.

Figure 6 shows CIE $x, y$ chromaticity diagram of EL device with $\mathrm{ZnS}: \mathrm{Cu}$ phosphor change in thickness which responded to green-blue color. The $x, y$ chromaticity CIE standard was shown in Table 1 which demonstrated an $x, y$ CIE standard of $\mathrm{ZnS}: \mathrm{Cu}$ phosphor EL devices in the condition of the thickness $10 \mu \mathrm{m}, 30 \mu \mathrm{m}$, and $50 \mu \mathrm{m}$. The $x, y$ CIE standard was average at $x=0.1923$ and $y=0.4788$ which is shown $x, y$ chromaticity diagram in Figure 6.

The luminance of EL device with $\mathrm{ZnS}: \mathrm{Cu}$ phosphor change in thickness $10 \mu \mathrm{m}, 30 \mu \mathrm{m}$, and $50 \mu \mathrm{m}$ is shown in Figure 7 . When the applied voltage and frequency on cell
TABLE 1: $x, y$ CIE standard of EL devices using ZnS:Cu phosphor.

\begin{tabular}{lccc}
\hline Thickness of $\mathrm{ZnS}: \mathrm{Cu}$ phosphor & $\mathrm{Lv}$ & $x$ & $y$ \\
\hline $10 \mu \mathrm{m}$ & 45.78 & 0.1945 & 0.4698 \\
$30 \mu \mathrm{m}$ & 51.22 & 0.1923 & 0.4788 \\
$50 \mu \mathrm{m}$ & 42.58 & 0.1933 & 0.4651 \\
\hline
\end{tabular}

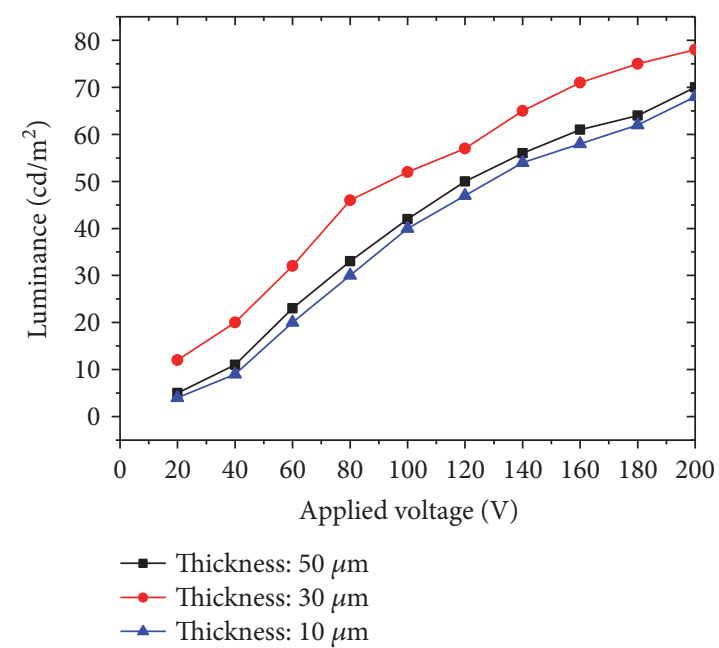

FIgURE 7: The luminance of EL device with $\mathrm{ZnS}: \mathrm{Cu}$ phosphor change in thickness $10 \mu \mathrm{m}, 30 \mu \mathrm{m}$, and $50 \mu \mathrm{m}$.

were $0-200 \mathrm{~V}$ and $400 \mathrm{~Hz}$, the voltage of the initial light emission was $20 \mathrm{~V}$ for all thickness and the luminance of EL device was $41.78 \mathrm{~cd} / \mathrm{m}^{2}$ for thickness of $10 \mu \mathrm{m}, 51.22 \mathrm{~cd} / \mathrm{m}^{2}$ for thickness of $30 \mu \mathrm{m}$, and $45.58 \mathrm{~cd} / \mathrm{m}^{2}$ for thickness of $50 \mu \mathrm{m}$ at $100 \mathrm{~V} 400 \mathrm{~Hz}$. The highest voltage of the initial light emission and intensity were thickness of $30 \mu \mathrm{m}$ due to the thickness more than $30 \mu \mathrm{m}$ cause the mean free path of the electron area on the surface of $\mathrm{ZnS}: \mathrm{Cu}$ phosphor is suitable and the efficient faradaic current flow through at $\mathrm{ZnS}: \mathrm{Cu}$ phosphor are decreased [27-29].

\section{Conclusions}

Electroluminescence (EL) device using the $\mathrm{ZnS}$ :Cu phosphor layer on ITO:PET was fabricated to investigate an effect on the luminescence properties. The performance of EL device with the $\mathrm{ZnS}: \mathrm{Cu}$ phosphor layer at thickness $30 \mu \mathrm{m}$ was shown to have a higher luminance than that of thickness at $10 \mu \mathrm{m}$ and $50 \mu \mathrm{m}$ at the same operation voltage. Moreover, all thickness had a $20 \mathrm{~V}$ of voltage for initial light emission. The electrical and luminance properties of EL device with $\mathrm{ZnS}: \mathrm{Cu}$ phosphor change in thickness at $30 \mu \mathrm{m}$ were $51.22 \mathrm{~cd} / \mathrm{m}^{2}$ and $41.9 \mathrm{~A} / \mathrm{m}^{2}$ which were more than those of the other thickness. The wavelength of $507 \mathrm{~nm}$ for peak intensity and the light of green color from EL device were not influenced by the change in thickness of $\mathrm{ZnS}: \mathrm{Cu}$ phosphor. The optimal thickness of the $\mathrm{ZnS}$ :Cu phosphor for EL device was thickness $30 \mu \mathrm{m}$, which results in significant increase of EL device efficiency. 


\section{Conflicts of Interest}

The authors declare that they have no conflicts of interest.

\section{Acknowledgments}

This work was supported by King Mongkut's University of Technology Thonburi (KMUTT), Thailand, under the project of the National Research University Project of Thailand's Office of the Higher Education Commission for financial support.

\section{References}

[1] M. Schadt, "Field-effect liquid-crystal displays and liquidcrystal materials: key technologies of the 1990s," Displays, vol. 13, no. 1, pp. 11-34, 1992.

[2] S. T. Lim, J. H. Moon, J. I. Won, M. S. Kwon, and D. M. Shin, "Light emitting efficiencies in organic light emitting diodes (OLEDs)," Studies in Interface Science, vol. 11, pp. 185-193, 2001.

[3] C. W. Tang and S. A. Vanslyke, "Organic electroluminescent diodes," Applied Physics Letters, vol. 51, no. 12, pp. 913-915, 1987.

[4] A. J. Bard, Electrogenerated Chemiluminescence, Marcel Dekker, New York, 2004.

[5] P. Chansri and Y. M. Sung, "Synthesis and characterization of $\mathrm{TiO}_{2}$ on $\mathrm{ZnO}$-nanorod layer for high-efficiency electrochemiluminescence cell application," Japanese Journal of Applied Physics, vol. 55, no. 2S, article 02BB11, 2016.

[6] H. Zhang, H. Chai, T. Yu, Y. Zhao, and D. Fan, "High-efficiency blue electroluminescence based on coumarin derivative 3-(4-(anthracen-10-yl)phenyl)-benzo[5,6]coumarin," Journal of Fluorescence, vol. 22, pp. 1509-1512, 2012.

[7] S. T. Henderson, "Electroluminescence," British Journal of Applied Physics, vol. 9, no. 2, pp. 45-51, 1958.

[8] H. Ivey, "Electroluminescence and semiconductor lasers," IEEE Journal of Quantum Electronics, vol. 2, no. 11, pp. 713726, 1966.

[9] U. Mitschke and P. Bäuerle, "The electroluminescence of organic materials," Journal of Materials Chemistry, vol. 10, pp. 1471-1507, 2000.

[10] L. Qian, Y. Zheng, K. R. Choudhury et al., "Electroluminescence from light-emitting polymer/ZnO nanoparticle heterojunctions at sub-bandgap voltages," NanoToday, vol. 5, no. 5, pp. 384-389, 2010.

[11] P. K. Shon, J. H. Shin, G. C. Kim, and S. N. Lee, "Enhanced luminescence related to transparent conductive oxide in ZnSbased EL device fabricated by screen printing method," Journal of Luminescence, vol. 132, no. 7, pp. 1764-1767, 2012.

[12] K. H. Buter, C. W. Jerome, and J. F. Waymouth, "The electroluminescent lamp: a new light source," Electrical Engineering, vol. 73, no. 6, pp. 524-528, 2013.

[13] W. Zhao, Z. Yang, B. Jiao, and Z. Wu, "Organic alternating current electroluminescence device based on $4,4^{\prime}$-bis(N-phenyl-1-naphthylamino) biphenyl/1,4,5,8,9,11-hexaazatriphenylene charge generation unit," Organic Electronics, vol. 17, pp. 44-50, 2015.

[14] Y. Xie and S. Qin, "Principle and application of inorganic electroluminescence and organic electroluminescence," in
International Conference on Electric Information and Control Engineering, ICEICE, pp. 6027-6029, Wuhan, China, 2011.

[15] I. Boonyaroonate and S. Mori, "Half-bridge inverter using hysteresis current control for electroluminescent lamp," in IEEE Region 10 International Conference on Electrical and Electronic Technology, pp. 796-798, Singapore, 2001.

[16] S. Jones, "Electroluminescence in oxide phosphors," Journal of Electrochemistry Society, vol. 111, no. 3, pp. 307-311, 1964.

[17] C. Chunkul, S. Arunrungrusmi, and P. Chansri, "Flyback DC/ AC inverter for large electroluminescent lamp," in International Conference on Applied Electrical and Mechanical Engineering (ICAEME 2015), August 27-28, pp. 273-275, Bangkok, Thailand, 2015.

[18] P. Chamsri and S. Y. Sung, "A class D ZVS DC/AC inverter for large electroluminescent lamp," in KIEE Annual Spring Conference, p. 175, Gwang-ju, South Korea, 2015.

[19] T. Kryshtab, V. S. Khomchenko, J. A. Andraca-Adame et al., "Preparation and properties of thin $\mathrm{ZnS}: \mathrm{Cu}$ films phosphors," Thin Solid Films, vol. 515, pp. 513-516, 2006.

[20] J. H. Park, S. H. Lee, J. S. Han, A. K. Kwon, H. L. Park, and S. D. Han, "White-electroluminescent device with $\mathrm{ZnS}: \mathrm{Mn}, \mathrm{Cu}, \mathrm{Cl}$, phosphor," Journal of Luminescence, vol. 126, pp. 566-570, 2007.

[21] Y. Bacherikov, A. Kuchuk, A. Zhuk, Y. Polischuk, V. Kladko, and T. Kryshtab, "Correlation between luminescent characteristics and phase composition of $\mathrm{ZnS}: \mathrm{Cu}$ powder prepared by self-propagating high-temperature synthesis," Journal of Luminescence, vol. 145, pp. 970-975, 2014.

[22] W. Wang, F. Huang, Y. Xia, and A. Wang, "Improved electroluminescence performance of $\mathrm{ZnS}: \mathrm{Cu}, \mathrm{Cl}$ phosphors by ultrasonic treatment," Journal of Luminescence, vol. 128, pp. 199-204, 2008.

[23] A. Klausch, H. Althues, C. Schrage et al., "Preparation of luminescent $\mathrm{ZnS}: \mathrm{Cu}$ nanoparticles for the functionalization of transparent acrylate polymers," Journal of Luminescence, vol. 130, pp. 692-697, 2010.

[24] S. D. Han, I. Singh, D. Singh, Y. H. Lee, G. Sharma, and C. H. Han, "Crystal growth of electroluminescent phosphor and its $\mathrm{TiO} 2$ coating by the sol-gel method for thick-film EL device," Journal of Luminescence, vol. 115, pp. 97-103, 2005.

[25] J. Y. Kim, "High performance of the organic-inorganic powder electroluminescence device with high color-rendering capability using the multilayer," Optics Communications, vol. 321, pp. 86-89, 2014.

[26] P. Chansri, D. J. Kwak, and Y. M. Sung, "Production and operating characteristics for inorganic EL phosphor," in KIEE Summer Conference, pp. 1132-1133, Muju, South Korea, 2015.

[27] W. Kaiser, R. P. Marques, and A. F. Correa, "Light emission of electroluminescent lamps under different operating conditions," IEEE Transactions on Industry Applications, vol. 49, no. 5, pp. 2361-2369, 2013.

[28] C. Zhanga, B. Qiao, S. Zhao et al., "Transient analysis of stored charges in organic light-emitting diodes and their application in alternating current driven electroluminescence," Organic Electronics, vol. 39, pp. 348-353, 2016.

[29] G. Sharma, S. D. Han, J. D. Kim, S. P. Khatkar, and Y. W. Rhee, "Electroluminescent efficiency of alternating current thick film devices using $\mathrm{ZnS}: \mathrm{Cu}, \mathrm{Cl}$ phosphor," Materials Science and Engineering: B, vol. 131, no. 1-3, pp. 271-276, 2006. 

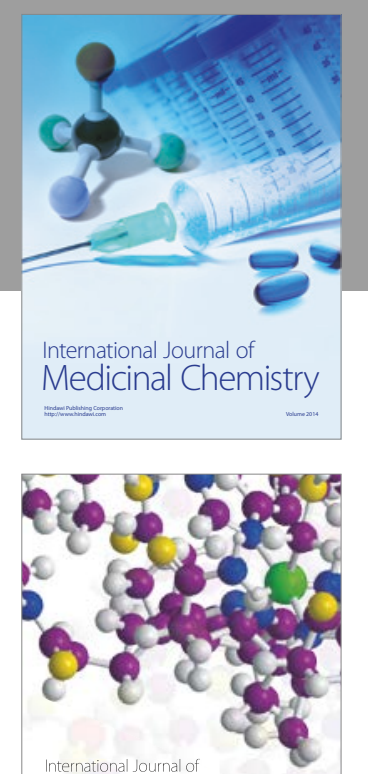

Carbohydrate Chemistry

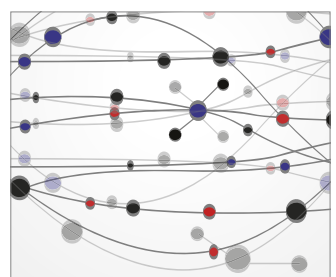

The Scientific World Journal
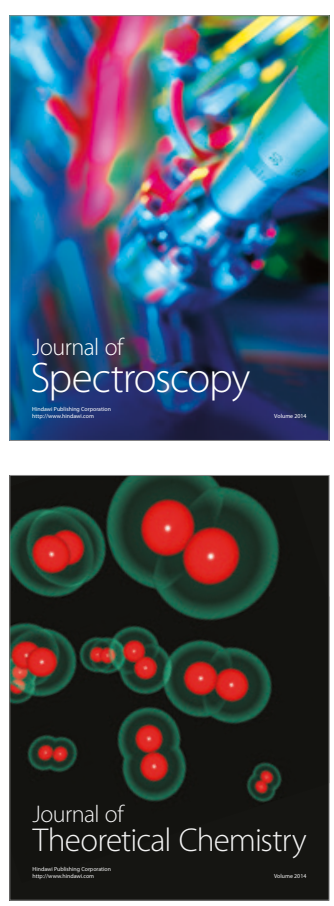
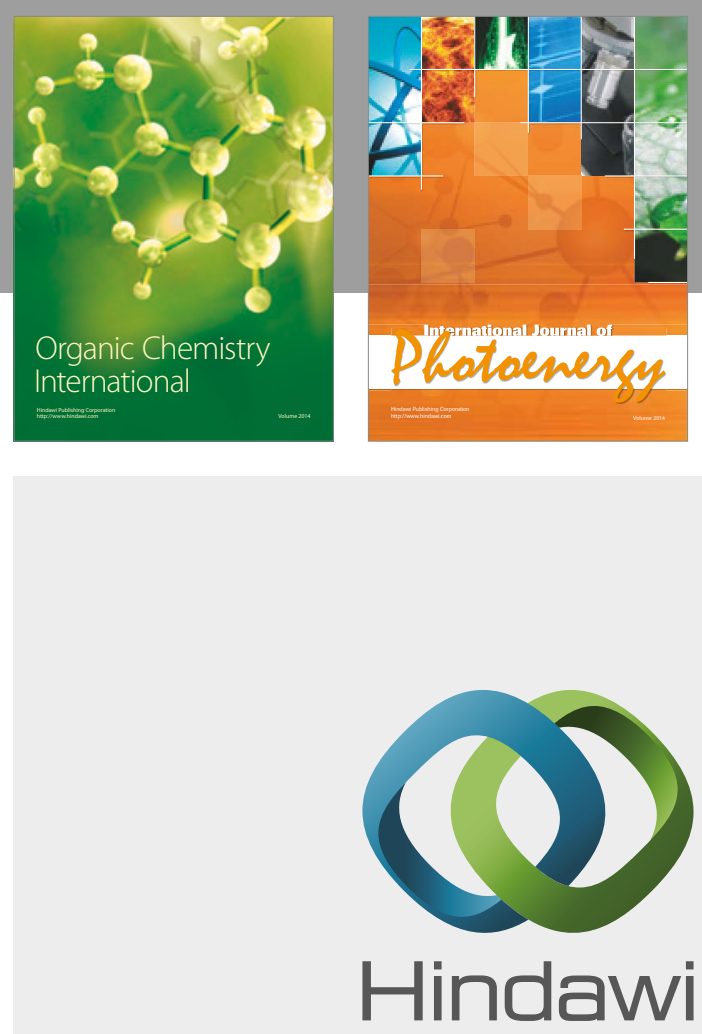

Submit your manuscripts at

https://www.hindawi.com

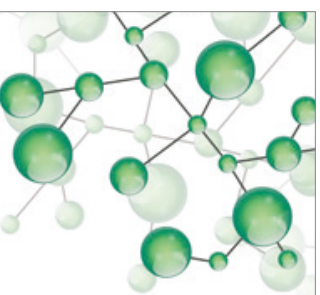

International Journal of

Inorganic Chemistry

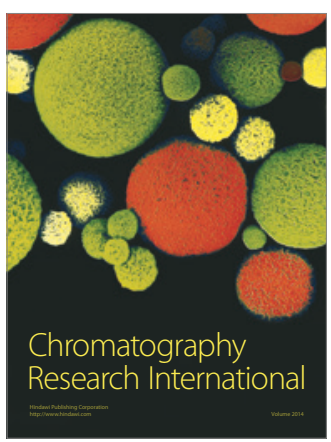

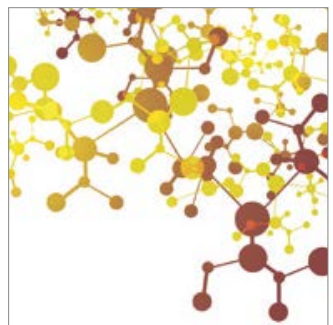

Applied Chemistry
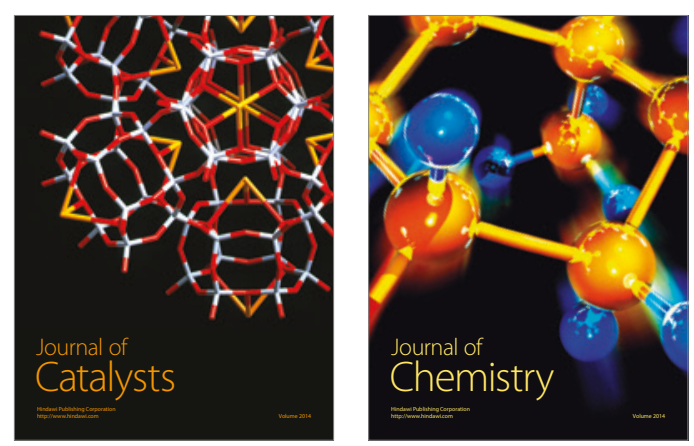
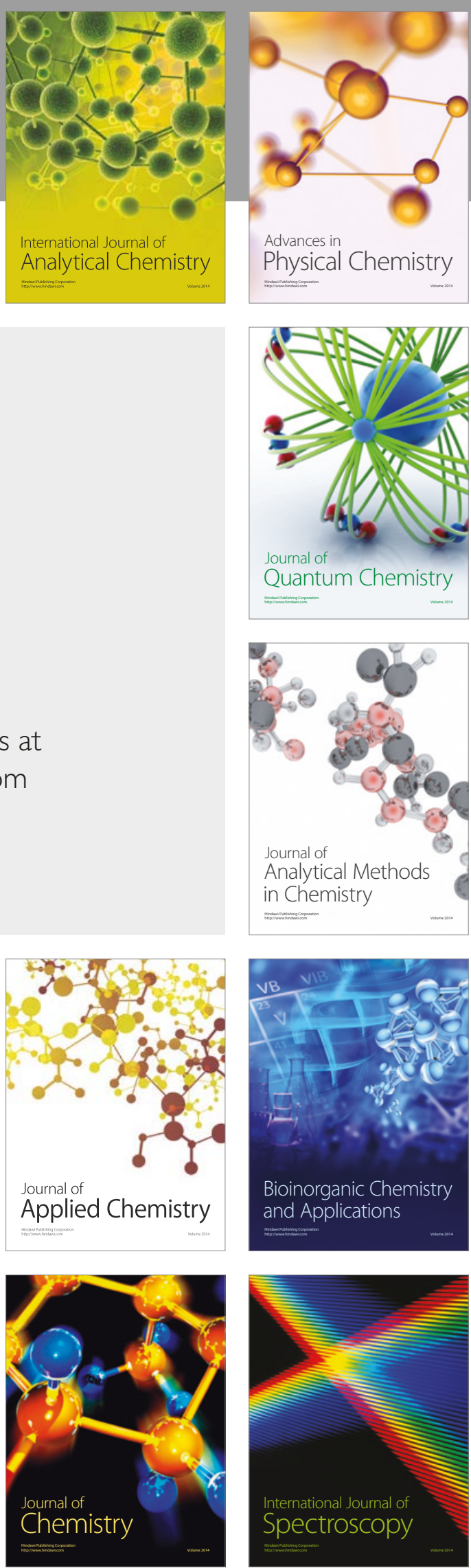